\title{
Particulate Matter and Subjective Respiratory Health Effect Measurements in Palembang during Forest Fire Episode in October 2015
}

Doni Hikmat Ramdhan, Zuly Prima Rizky, Hardy Atmajaya, and Anisa Kurniati

Occupational Health and Safety Department, Faculty of Public Health, Universitas Indonesia, Jakarta, Indonesia

\section{Abstract}

Particulate matter is a mixture of solid particles and liquid droplets that can gather in the atmosphere. Wild land fires are uncontrollable land fires that consume combustible plants and emit significant amounts of carbon dioxide, methane, non-methane volatile organic compounds, nitrogen oxides, and particulates. This research was conducted to measure the fine particulate matter $\left(\mathrm{PM}_{2.5}\right)$ pollution during October 2015 that was caused by a September forest fire in Palembang, one of the cities most affected

Corresponding Author: Doni Hikmat Ramdhan doni@ui.ac.id

Received: 21 January 2018 Accepted: 8 April 2018

Published: 17 May 2018

Publishing services provided by Knowledge

(c) Doni Hikmat Ramdhan et al. This article is distributed under the terms of the

which permits unrestricted use and redistribution provided that the original author and source are credited.

Selection and Peer-review under the responsibility of the 2nd International Meeting of Public Health 2016 Conference Committee. by wildfires in Indonesia. Sampling was based on the United States Environmental Protection Agency (US EPA) IP 10-A Method updated by SKC Ltd and was conducted every day for a week for six hours each day, divided into morning and evening sequences. Coarse and fine particles were filtered using a Sioutas Impactor and a Leland Legacy personal pump with a flow rate of $9 \mathrm{~L} / \mathrm{min}$. Quartz fiber filters were placed in every stage of the impactor to collect the particles. Particulate matter (PM) concentration was measured using the gravimetric method. The weighing was done using a Mettler Toledo MX5 microbalance. Questionnaires were used to gather information on health problems from 63 adults and 54 children from Palembang. The mean concentrations of coarse and fine particulate matter $\left(\mathrm{PM}_{10}\right.$ and $\left.\mathrm{PM}_{2.5}\right)$ in Palembang during the measurement periods were determined to be $818.78 \mu \mathrm{g} / \mathrm{m}^{3}$ and $672.99 \mathrm{\mu g} / \mathrm{m}^{3}$ respectively. The peak measurements for the 24 -hour mean concentrations of $\mathrm{PM}_{10}$ and $\mathrm{PM}_{2.5}$ on October 21,2015 were $1,369.34 \mu \mathrm{g} / \mathrm{m}^{3}$ and 1,246.92 $\mathrm{\mu g} / \mathrm{m}^{3}$ respectively. Both $\mathrm{PM}$ groups exceeded the 24 -hour standards for $\mathrm{PM}_{10}$ and $\mathrm{PM}_{2.5}$ concentrations outlined in the WHO Air Quality Guidelines and the US EPA National Ambient Air Quality Standards. Based on the results of the questionnaires, more than two-thirds of both children and adults experienced sneezing, nasal congestion, influenza, and dry cough during the forest fire episode. In conclusion, the particle pollution in Palembang city that was caused by the forest fire was hazardous to human health, and further research is needed to explore the health effects resulting from forest fire pollution that may affect Palembang's citizens. 


\section{INTRODUCTION}

Solid particles and liquid droplets smaller than $2.5 \mu \mathrm{m}$ suspended in the air are known as fine particulate matter $\left(\mathrm{PM}_{2.5}\right)$ [19]. Fine particulate matter is formed by primary and secondary processes. The primary process of fine particulate matter formation involves the condensation of high-temperature vapor during combustion, while the secondary process involves nucleation, gas condensation onto existing particles, and gas absorption into liquid droplets [8]. An uncontrollable fire that consumes dried vegetation, or a wildfire, emits an abundance of complex gasses and aerosol mixtures into the air [17]. Carbon dioxide, methane, non-methane volatile organic compounds, nitrogen oxides, and aerosol are major pollutants from wildfires [17].

Wild land fires have occurred annually at several locations in Indonesia since 1997 [1]. The ability of fine particles to travel up to a thousand kilometers makes wildfire pollution a regional problem that affects neighboring countries [17]. It is estimated that 339,000 death shave occurred globally every year because of wild land fire smoke, while the highest proportion of deaths occurs in Southeast Asia with 110,000 deaths per year (Johnston et. al, 2010). Exposure to fine particles from wildfires is also associated with an increase in heart attack risk outside of hospitals, while coarse particulate matter $\left(\mathrm{PM}_{10}\right)$ from wildfires is associated with an increase in respiratory disease, chronic obstructive pulmonary disease, and adult asthma [11]. This research aimed to measure the $\mathrm{PM}_{2.5}$ pollution and subjective respiratory health effects from September to October 2015 that were caused by a September forest fire in Palembang, one of the most affected cities in Indonesia.

\section{METHODS}

Fine particles and subjective respiratory health effect data were collected in the Sukabangun district of Palembang city, located in the middle of the South Sumatra province. Palembang is located between $-2^{\circ} 52^{\prime} \mathrm{S}$ and $-3^{\circ} 5^{\prime} \mathrm{S}$ latitude and $104^{\circ} 37^{\prime} \mathrm{E}$ and $104^{\circ} 52^{\prime} \mathrm{E}$ longitude and situated five meters above sea level. South Sumatra has an abundance of fire hot spots, with up to 239 spots during 2015.

\subsection{Particulate Matter Measurement}

$\mathrm{PM}_{2.5}$ was collected according to the US EPA IP 10-A Method updated by SKC [13]. A Sioutas Cascade Impactor was used to collect and separate coarse and fine particles 


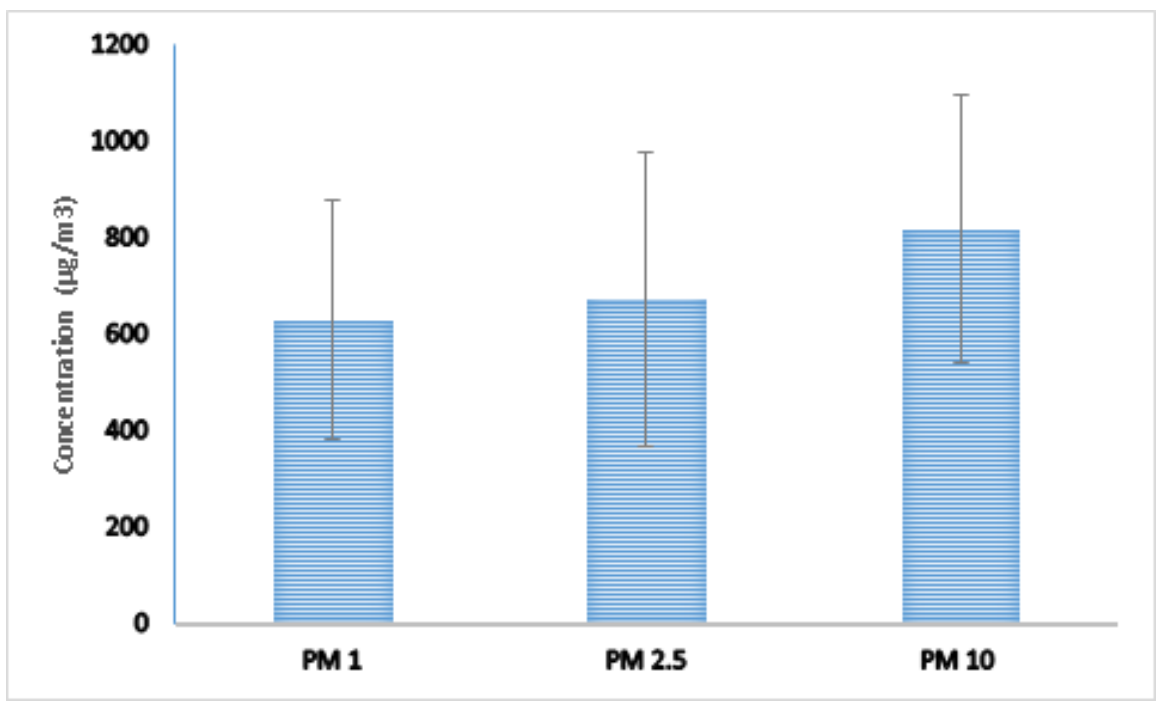

Figure 1: Particulate matter mean concentrations at the Sukabangun district in Palembang city during the smoke period, October 2015.

according to their size. The impactor was filled with five quartz fiber filters and attached to a Leland Legacy personal pump running at $\mathrm{gL} / \mathrm{min}$. The PM measurement apparatus was located indoors in two different locations. Sampling was conducted from October 15 to 21,2015 , for six hours each day, divided into morning and evening periods of three hours each. The particulate matter concentration was measured by the gravimetric method using a microbalance.

\subsection{Subjective Respiratory Health Effect Measurements}

Subjective respiratory health effects were measured using a questionnaire adapted from the American Thoracic Society. The chosen respondents were 63 adults and 54 children from the Sukabangun district. The questionnaire was used to measure acute respiratory and other health problems from two weeks after and one year prior to the fire.

Figure ?? illustrates the particulate matter concentrations in the Sukabangun district in Palembang city during the smoke period. Ultrafine $\left(P M_{1}\right)$, fine $\left(P M_{2.5}\right)$, and coarse $\left(\mathrm{PM}_{10}\right)$ particles were collected in two different locations in the Sukabangun district for seven consecutive days. The 24-hour mean concentrations of $\mathrm{PM}_{1}, \mathrm{PM}_{2.5}$, and $\mathrm{PM}_{10}$ were $632.13 \pm 247.71 \mu \mathrm{g} / \mathrm{m}^{3}, 672.6 \pm 305.55 \mu \mathrm{g} / \mathrm{m}^{3}$, and $818.78 \pm 279.6 \mu \mathrm{g} / \mathrm{m}^{3}$ respectively. Both $\mathrm{PM}_{2.5}$ and $\mathrm{PM}_{10}$ concentrations exceeded both US EPA National Ambient Air Quality Standards and WHO Air Quality Guidelines [18, 21]. 


\section{Subjective Respiratory Health Effects}

Data were collected from 63 adults between 18 and 68 years old, at a 23:40 male to female ratio. These data were collected in October during the same period as the particulate matter measurements. Based on respondent opinions, the smoke period started in early September and lasted up to the time the interview was conducted. Sneezing two weeks before the start of the smoke period was reported by $83 \%$ of respondents, while60\% also stated that they had experienced nasal congestion and dry cough, and $63 \%$ indicated that they had experienced influenza during the same time frame. Regarding non-respiratory effects, $58.73 \%$ and $65.08 \%$ of adults suffered from red and itchy eyes during the smoke period.

Similar results were collected from 54 children in the same area and at the same time. Sneezing and nasal congestion affected $83 \%$ and $61 \%$ of these children respectively, while $67 \%$ suffered from both influenza and dry cough. Non-respiratory effects showed small differences from the adult group; $46 \%$ of the children suffered from itchy eyes, and $41 \%$ of the children experienced fever during the forest fire period.

\section{DISCUSSION}

The mean concentration of $\mathrm{PM}_{10}$ found in this study is three times the normal monthly mean concentration in Palembang as measured by "Badan Metorologi, Klimatologi dan Geofisika" (BMKG) (the Indonesian Agency for Meteorology, Climatology, and Geophysics) [2]. September and October have the highest $\mathrm{PM}_{10}$ concentration levels during 2015, reaching 304.43 and $349.74 \mu \mathrm{g} / \mathrm{m}^{3}$ respectively. This trend is similar to that of the year before, in which September, October, and November had the highest $\mathrm{PM}_{10}$ concentration levels, peaking in October at $292.37 \mathrm{\mu g} / \mathrm{m}^{3}$. A wild land fire that occurred in South Sumatra during that period was the main cause of this increase.

Several studies show that forest fires, bush fires, and other types of wild land fires are responsible for high concentrations of PM. During a forest fire period, $\mathrm{PM}_{10}$ and $\mathrm{PM}_{2.5}$ concentrations in Sobreiras were respectively halved and doubled when compared to their mean concentrationsat another time [14]. Also due to forest fires, $\mathrm{PM}_{10}$ concentrations in California, British Columbia, and Athens peaked at 200, 248.4, and $96 \mu \mathrm{g} / \mathrm{m}^{3}$ respectively $[3,6,20]$. Measurements taken by firefighters during forest fire periods in Australia also show remarkable levels of respirable particles, with the highest recorded concentration from 11 samples being 3,800 $\mu \mathrm{g} / \mathrm{m}^{3}$ [12]. 
Particulate matter in all size categories is notorious for its adverse effects on human health. A study on particles released from wild land fires in Alaska shows that coarse and ultrafine particles contain abundant levels of carbon and $\mathrm{OH}$ radicals respectively [9]. This study shows that all sizes of particles can cause DNA damage. Another study on seasonal forest firefighters found that acute exposure to forest fire emissions can induce inflammation within the lungs and initiate a systemic inflammatory response [15]. Forest fire smoke has also been associated with an increased number of respiratory complaints in Kelowna, British Columbia [10]. In children's health, wildfire exposure has been associated with the development of eye and respiratory symptoms and an increase in medication use and physician visits [5]. Increased concentrations of $\mathrm{PM}_{10}$ have also been associated with increased hospital admissions in British Colombia, Canada and Victoria, Australia $[4,16]$.

\section{CONCLUSION}

The mean concentrations of $\mathrm{PM}_{10}$ and $\mathrm{PM}_{2.5}$ in Palembang during the measurement periods were $818.78 \mu \mathrm{g} / \mathrm{m}^{3}$ and $672.99 \mu \mathrm{g} / \mathrm{m}^{3}$ respectively. The peak levels for the $24^{-}$ hour mean concentrations of $\mathrm{PM}_{10}$ and $\mathrm{PM}_{2.5}$ on October 21,2015 were $1,369.34 \mathrm{\mu g} / \mathrm{m}^{3}$ and 1,246.92 $\mathrm{\mu g} / \mathrm{m}^{3}$ respectively. Both PM groups exceeded the WHO Air Quality Guidelines and US EPA National Ambient Air Quality Standards 24-hour standards for $\mathrm{PM}_{10}$ and $\mathrm{PM}_{2.5}$ concentrations $[18,21]$. Based on the results of the questionnaires, more than two-thirds of both children and adults experienced sneezing, nasal congestion, influenza, and dry cough during the forest fire episode. The particle pollution in Palembang city that was caused by the forest fire was hazardous to human health, and further research is needed to elaborate on the health effects resulting from forest fire pollution that may affect Palembang's citizens.

\section{ACKNOWLEDGEMENTS}

We gratefully acknowledge that this study was funded by the Directorate of Research and Community Services of Universitas Indonesia.

\section{References}

[1] Badan Meteorologi Klimatologi Dan Geofisika. Bencana Kebakaran Hutan dan Lahan Menjadi Perhatian Bersama; [Internet]. 2015. Available from: 
http://bmkg.go.id/BMKG_Pusat/Sestama/Humas/\%OABENCANA_KEBAKARAN_HUTAN_ DAN_LAHAN_MENJADI_PERHATIAN_BERSAMA.bmkg.\%OA.

[2] Badan Meteorologi Klimatologi dan Geofisika. Partikulat Matter 10 Mikron (PM10) Periode 2014-2015 [Internet]. 2016. Available from: http://www.bmkg.go.id/ kualitas-udara/informasi-partikulat-pm10.bmkg

[3] Henderson SB, Brauer M, MacNab YC, Kennedy SM. Three Measures of Forest Fire Smoke Exposure and Their Association with Respiratory and Cardiovascular Physician Visits and Hospital Admissions. Environ Health Perspect. 2009;119(9):1266-71. Available from: https://ehp.niehs.nih.gov/1002288/

[4] Henderson SB, Brauer M, Macnab YC, Kennedy SM. Three measures of forest fire smoke exposure and their associations with respiratory and cardiovascular health outcomes in a population-based cohort. Environ Health Perspect. 2011 Sep;119(9):1266-71.

[5] Kunzli N, Avol E, Wu J, Gauderman WJ, Rappaport E, Millstein J, et al. Health effects of the 2003 Southern California wildfires on children. Am J Respir Crit Care Med. 2006 Dec;174(11):1221-8.

[6] Liu Y, Kahn RA, Chaloulakou A, Koutrakis P. Analysis of the impact of the forest fires in August 2007 on air quality of Athens using multi-sensor aerosol remote sensing data, meteorology and surface observations. Atmos Environ. 2009;43(21):3310-8. Available from: http://www.sciencedirect.com/science/ article/pii/S1352231009003252

[7] Johnston FH, Henderson SB, Chen Y, Randerson JT, Marlier M, Defries RS, et al. Estimated global mortality attributable to smoke from landscape fires. Environ Health Perspect. 2012 May;120(5):695-701.

[8] Lippmann M. Environmental Toxicants: Human Exposures and Their Health Effects [Internet]. Wiley; 2009. Available from: https://books.google.co.id/books?id= yGpgxOuuNXAC.

[9] Leonard SS, Castranova V, Chen BT, Schwegler-Berry D, Hoover M, Piacitelli C, et al. Particle size-dependent radical generation from wildland fire smoke. Toxicology. $2007 \mathrm{Jul} ; 236(1-2): 103-13$.

[10] Moore D, Copes R, Fisk R, Joy R, Chan K, Brauer M. Population health effects of air quality changes due to forest fires in British Columbia in 2003: estimates from physician-visit billing data. Can J Public Health. 2006;97(2):105-8

[11] Morgan G, Sheppeard V, Khalaj B, Ayyar A, Lincoln D, Jalaludin B, et al. Effects of Bushfire Smoke on Daily Mortality and Hospital Admissions in Sydney, Australia. Epidemiology. 2010 Jan;21(1):47-55. 
[12] Reisen F, Brown SK. Australian firefighters' exposure to air toxics during bushfire burns of autumn 2005 and 2006. Environ Int. 2009 Feb;35(2):342-52

[13] SKC Inc. IP-10A Method Update. Update. 2004.

[14] Slezakova K, Delerue-Matos C, Alvim-Ferraz MC, Morais S, Pereira MC. Influence of forest fires on levels of PM10 and PM2.5 in northern region of Portugal: preliminary study. Proceeding Glob Conf Glob Warm 2011. 2011;(11-14, 2011).

[15] Swiston JR, Davidson W, Attridge S, Li GT, Brauer M, van Eeden SF. Wood smoke exposure induces a pulmonary and systemic inflammatory response in firefighters. Eur Respir J. 2008 Jul;32(1):129-38.

[16] Tham R, Erbas B, Akram M, Dennekamp M, Abramson MJ. The impact of smoke on respiratory hospital outcomes during the 2002 - 2003 bushfire season, Victoria , Australia.

[17] Urbanski SP, Hao WM, Baker S. Chemical Composition of Wildland Fire Emissions. Dev Environ Sci. 2009;8(8):79-10.

[18] United States Environmental Protection Agency. National Ambient Air Quality Standards (NAAQS) National Ambient Air Quality Standards (NAAQS). 2014; Available from: https://www.epa.gov/sites/production/files/2015-02/documents/ criteria.pdf.

[19] United States Environmental Protection Agency. Particulate Matter (PM) [Internet]. 2016. Available from: https://www.epa.gov/pm-pollution.

[20] Wegesser TC, Pinkerton KE, Last JA. California Wildfires of 2008: Coarse and Fine Particulate Matter Toxicity. Vol. 117, Environmental Health Perspectives. 2009. p. 893-7.

[21] World Health Organization. Ambient (outdoor) air quality and health. 2016; Available from: http://www . who.int/mediacentre/factsheets/fs313/en/. 